|||||||||||||||||||||||||||||||||||

研究論文

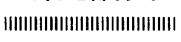

\title{
一方向凝固させた $\mathrm{Al}-\mathrm{Si}$ 合金鋳塊中の水素拡散*
}

\author{
市村稔**。篠嶋妥**
}

Hydrogen diffusivity in $\mathrm{Al}-\mathrm{Si}$ alloy ingots solidified unidirectionally

Minoru ICHIMURA** and Yasushi SASAJIMA**

\begin{abstract}
Hydrogen diffusivity in $\mathrm{Al}-(2-14$ mass\%) Si alloy ingots melted in nitrogen gas flow and solidified unidirectionally were measured by a vacuum hot extraction method. The diffusivity of $D_{1}$ for as-cast samples decreased to $D_{2}$ for hydrogen-charged and extracted samples, under an influence of the heating effects. The differences between $D_{1}$ and $D_{2}$ increased at the lower temperatures and with amounts of eutectics. The heating effects attended with the decreasing of diffusivity were due to two phenomena. The first was a loss of a long-range enhanced diffusion paths along the surfaces on the thin plate-like particles of eutectic silicon in as-cast samples, and the second was a grow-up of hydrogen trapping at the large granular silicon particles precipitated in $\alpha$-aluminum at around $673 \mathrm{~K}$. The hydrogen solubilities in $\mathrm{Al}-\mathrm{Si}$ alloys increased with the concentration of silicon.
\end{abstract}

Keywords: hydrogen, diffusivity, $\mathrm{Al}-\mathrm{Si}$ alloy, unidirectional solidification, eutectic silicon

(Received December 28, 1992)

\section{1. 緒言}

アルミニウムおよびその合金中の水素溶解ならびに払 散に関する研究は比較的少なく，他の金属や合金に比べ て水素の挙動は必ずしも十分明らかとはいえない。たと えば，純アルミニウム中の水素拡散係数の測定値間の非 常に大きなばらつきは古くから知られているが，その原 因はまだ十分明らかでない。最近，著者らは鋳造がス欠 陷（水素気泡に基づくボイド）1，2）や格子構造欠陥（結 晶粒界 $)^{3), 4)}$ が拡散係数のばらつきの最重要因子である ことを指摘した。

一方, アルミニウム合金中の水素払散係数の報告はさ らに少ない。わずかに以下の 3 件である。すなわち,

(1) Eborall と Ransley ${ }^{5)}$ は Al-7 mass\% Mg 合金におい て次式を得た。

$$
\begin{aligned}
D= & 3.4 \times 10^{-2}\left(\mathrm{~m}^{2} / \mathrm{s}\right) \exp [-103(\mathrm{~kJ} / \mathrm{mol}) / R T], \\
& 616 \sim 772 \mathrm{~K}
\end{aligned}
$$

ここで, $D:$ 拡散係数, $R$ : 気体定数, $T:$ 温度である。

(2) 西と黒淵6) は大気溶解後ランズレー金型に鋳込ん
だ Al-4 mass\% $\%$ u 合金中の水素扗散係数として次式を 得た。

$$
D(818 \mathrm{~K})=2.9 \times 10^{-9}\left(\mathrm{~m}^{2} / \mathrm{s}\right)
$$

(3) 最近, Anyalebechi ${ }^{7)}$ は Al-1 mass\% $\%$ Li 合金で次式 を得た。

$$
D=2.34 \times 10^{-8}\left(\mathrm{~m}^{2} / \mathrm{s}\right) \exp [-18.98(\mathrm{~kJ} / \mathrm{mol}) / R T],
$$

$$
523 \sim 873 \mathrm{~K}
$$

このように, アルミニウム合金中の水素挙動に関する研 究状況はきわめて不十分であり，より系統的な実験デー タの蓄積が必要である。そこで, 代表的かつ基礎的なア ルミニウム 2 元系合金中の水素挙動を明らかにするため に, $\mathrm{Al}-\mathrm{Cu}$ 合金鋳塊 ${ }^{8), 9}$ に㧍ける鋳塊組織（構成相と界 面）の影響について検討し, 次に, $\mathrm{Al}-\mathrm{Si}$ 合金鋳塊 ${ }^{10)} に$ おける鋳塊組織と加熱による水素挙動の変化について検 討し，報告した。

本研究では $\mathrm{Al}-\mathrm{Si}$ 合金中の水素拡散挙動とシリコン粒 子形態の関係をより明確にするために, 窒素雾囲気気流 中での一方向凝固鋳塊試料を用いて水素払散係数と溶解 度を実測し，従来の結果と比較検討することを目的とし

* 軽金属学会研究委員会, 第78回鋳造凝固部会（平成 3 年 6 月）で一部発表。

** 茨城大学工学部物質工学科 (日立市)。Department of Materials Science, Faculty of Engineering, Ibaraki University (Hitachi-shi, Ibaraki). 
た。本研究で一方向凝固試料を作製した理由は二つあ る。一つは前報10)の大気溶解金型凝固試料において懸念 されたガス欠陥（微小ボイド）を作らないようにするこ と, もら一つは初晶 $\alpha$ デンドライトや初晶シリコンを なるべく大きく凝固方向に沿って配列させるとともに， より大きな板状共晶シリコンを形成させることによっ て，でさるだけ単純な鋳塊組織を与えることである。つ まり，単純な鋳塊組織は水素拡散に対する構成相や境界 面の影響を考える上でより好都合であるからである。

\section{2. 試料作製および実験方法}

純アルミニウム（4 $\mathrm{N}=99.99$ mass\%）と $5 \mathrm{~N}$ の純シリ コンを抵抗炉, 大気中, $1023 \sim 1073 \mathrm{~K}$ で溶解し, 室温 の円筒金型に鋳造（前報 ${ }^{10)}$ の $\mathrm{Al}-\mathrm{Si}$ 合金 $\mathrm{AM}$ 鋳塊に相 当）した後，縦型管状電気炉により窒素気流中で再溶解 し, 約 $1.7 \times 10^{-5}(\mathrm{~m} / \mathrm{s})$ の速度で電気炉を引上げて一方 向に凝固させて， $\phi 25 \times 120 \mathrm{~mm}$ の円柱状鋳塊を作製し た。これを ND 鋳塊とよぶ。合金は 6 種類で, 亜共晶, 共晶, 過共晶組成にわたる $\mathrm{Al}-\mathrm{Si}$ 合金鋳塊 (1.99，5.66， $6.53,9.42,11.40,14.26$ mass\% $\% \mathrm{Si}$ ) である。これらをそ れぞれ 2ND, 6ND, 7ND, 9ND, 11ND, 14ND とよぶ。鋳 塊の上, 中, 下部から組織観察用の小試料 $(\phi 18 \times 5$ $\mathrm{mm}$ ）を採取した後，旋盤のドライカットで各鋳塊あた り 4 個の小円柱状試料 $(\phi 18 \times 25 \mathrm{~mm})$ を同軸方向に切 出し, ガス分析試料とした。なお，光顕組織観察によれ ば, 鋳塊の上下で一方向凝固に伴ら偏析等によるミク口 組織の差は特に認められなかった。全試料の重量と寸法 測定後, 真空加熱ガス抽出装置 ${ }^{1), 2}$ にセットし, 次の手 順で，抽出ガス圧を測定することから水素の挙動を検討 した。(1) 鋳造のまま（As cast）の試料を定容積真空 中で773 K 以下のいくつかの温度（低温から高温まで） で階段状に加熱保持して脱ガスする。それぞれの階段保 持温度における初期ガスの拡散係数 $\left(D_{1}\right)$ と初期ガス 量 $\left(C_{0}\right)$ を求める。(2) $5000 \sim 10000 \mathrm{~Pa}$ の範囲での定 圧純水素ガス雲囲気中で定温長時間加熱（たと党ば， $823 \mathrm{~K}-2 \mathrm{~h}, 573 \mathrm{~K}-20 \mathrm{~h}$ 等) 後, 同装置内で急冷して, 熱的水素チャージを行う。なお, 水素チャ一ジ圧力 $\left(P_{\mathrm{H}_{2}}\right)$ は水素量 $(C)$ および水素溶解度 $(S)$ との間に ジーベルッの関係, $C=S \cdot \sqrt{P_{\mathrm{H}_{2}}}$ をもつ。(3) 再び定容積 真空中で(1)と同様に加熱して水素ガス抽出曲線を求め, 抽出ガス圧と抽出速度から水素ガス量 $(C)$, 水素溶解 度 $(S)$ および水素チャージ試料中の水素拡散係数 $\left(D_{2}\right)$ を求める。さらに, これらのガス抽出実験の前後で, (1) 室温トルェン重量法による密度測定, (2)マイクロビッカ 一ス硬度測定および(3)光学顕微鏡組織観察を行って, 一 連の実験に伴う加熱の影響を調べる。

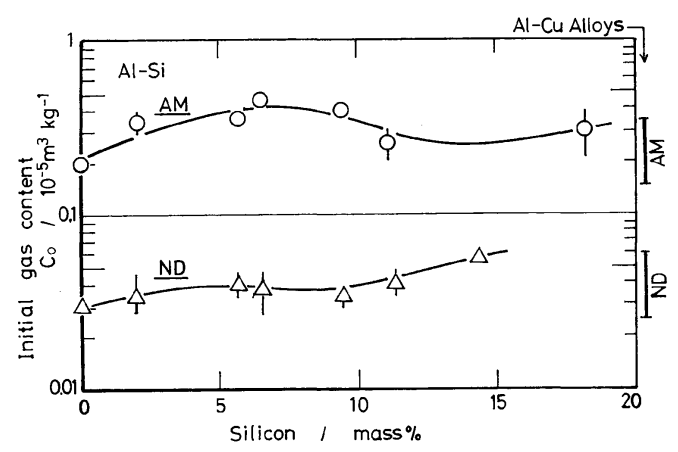

Fig. 1 Relation between the silicon concentration and the initial gas content $\left(C_{0}\right)$ in as cast samples for ND ingots solidified unidirectionally in nitrogen gas flow, and a comparison with that for AM ingots melted in air and for $\mathrm{Al}-\mathrm{Cu}$ alloys of $\mathrm{AM}$ and ND ingots.

\section{3. 実験結果および考察}

As cast 試料からの脱ガスによって得られた初期ガス 量 $\left(C_{0}\right)$ の測定結果を Fig. 1 に示す。比較のために前 報10)の $\mathrm{AM}$ 鋳塊の $C_{0}$ と $\mathrm{Al}-\mathrm{Cu}$ 合金 ${ }^{8)} の C_{0}$ を合わせて 示した。 $C_{0}$ はシリコン濃度にほとんど依存しないこと， $\mathrm{ND}$ のガスレベルは AM の約 $1 / 10$ であること, $\mathrm{Al}-\mathrm{Cu}$ 合金とも大体同じであることがわかった。

Fig. 2 は本実験で得られたすべての拡散係数のアレニ ウスプロットである。四の上から下へ (2ND $\rightarrow 14 \mathrm{ND})$ シリコン濃度が増加する。ここで, 実線の直線 (0ND) は同条件で一方向凝固させた $4 \mathrm{~N}$ 純アルミニウム単結晶 の結果 ${ }^{3)}$ であり, 本実験のデータの比較基準として次式 で与えられる。

$$
\begin{aligned}
D= & 9.53 \times 10^{-6}\left(\mathrm{~m}^{2} / \mathrm{s}\right) \exp [-44.3(\mathrm{~kJ} / \mathrm{mol}) / R T], \\
& 903 \sim 473 \mathrm{~K}
\end{aligned}
$$

図中, $\Delta$ 印はAs cast 試料からの脱がス過程で得られた 拡散係数 $\left(D_{1}\right)$ であり，11NDは373 K から，それ以外 の試料は $573 \mathrm{~K}$ から大体 $100 \mathrm{~K}$ の間隔で抽出温度を階段 状に上昇させて求めたものである。したがって, 高温の $D_{1}$ はより低温側での抽出加熱の影響を受けているため に，厳密にはAs cast の拡散係数とはいえない。しか

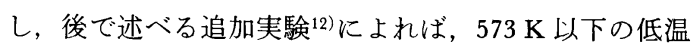
では加熱に伴ら鋳塊組織変化（つまり板状シリコンの分 断凝集粒状化）の影響が無視でき, As castの拡散係数 $\left(D_{1}\right)$ を示すと考えてよいと判断した。

ところで, ND 鋳塊の $C_{0}$ は $\mathrm{AM}$ 鋳塊の約 $1 / 10$ と小さ いために, 多段抽出実験による特に低温での $D_{1}$ 測定が 困難であった。唯一，11NDに対して低温側での $D_{1}$ を 得たが, 温度依存性については前報 ${ }^{10)} \mathrm{AM}$ の場合と同 


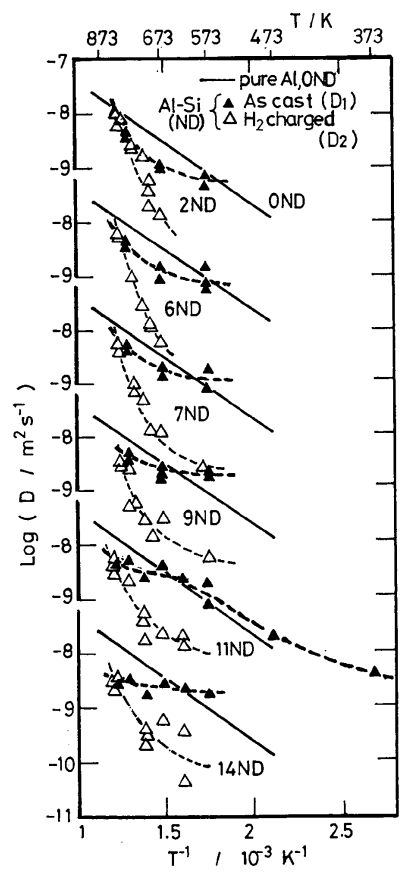

Fig. 2 Arrhenius type, semi-logarithmic, plot of the hydrogen diffusivities on the extraction temperatures for six $\mathrm{Al}-\mathrm{Si}$ alloys from $2 \mathrm{ND}$ to $14 \mathrm{ND}$ which are solidified unidirectionally in nitrogen gas flow. The diffusion coefficients do not obey the Arrhenius linear law, and they are decreased clearly by heating.

様で，そのアレニウスプロットは直線にならなかった。 このようなかなり複雑な温度依存性を示す原因は, 前

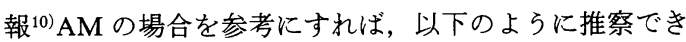
る。すなわち，0NDの拡散係数を基準にして低温側で 見られる $D_{1}$ の相対的な増加傾向は板状共晶シリコン表 面の高速拡散効果により，また，673〜 723 K 付近で見 られる $D$ の減少（下に凸）は過飽和固溶体（ $\alpha-\mathrm{Al} ）$ か らの析出シリコン粒子の水素トラップ効果によると思わ れる。

次に, 高温での水素チャージ後の拡散係数 $\left(\triangle \mathrm{N}^{-}, D_{2}\right)$ は $D_{1}$ に比べて明らかに減少した。その程度は低温ほど 大きく，573〜 673 K 付近で 2 桁にも達する。このよう な拡散係数の低下をもたらす加熱効果は前報 ${ }^{10)} \mathrm{AM} の$ 場合よりむさらに大きかった。 $\Delta$ 印 $\left(D_{2}\right)$ には水素チャ ージおよびガス抽出を数回繰返したデータも含まれてお り，特に区別していないが，2 回目以降の高温加熱の影 響は見られなかった。つまり，加熱効果のほとんどは As cast 脱ガス実験（ $D_{1} ， \Delta$ 印）の最終加熱（773〜823 K）扰よびその後の第一回水素チャージ加熱（823 K-2 h）の段階で完了する。

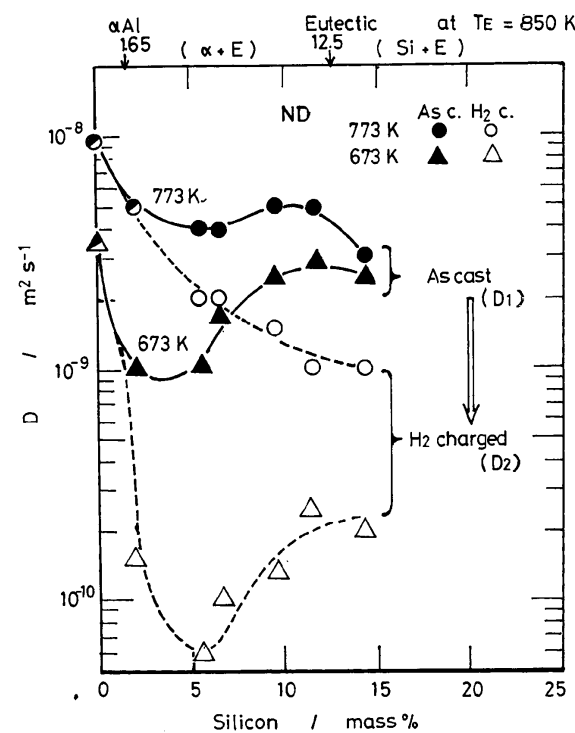

Fig. 3 Silicon concentration dependences of hydrogen diffusivities at $773 \mathrm{~K}$ and $673 \mathrm{~K}$ in the as cast and the hydrogen charged conditions. The diffusivity decreasing by heating is corresponded to an amount of eutectics.

Fig. 3 は拡散係数の合金組成依存性を見るために, Fig. 2 の破線から $673 \mathrm{~K}$ と $773 \mathrm{~K}$ の二つの温度での $D_{1}$ と $D_{2}$ を読み取り，シリコン濃度に対してプロットしたも のである。 $D_{1}, D_{2}$ 共にシリコン添加によって最初は減 少するが，共晶増加とともに再び増加する傾向がある。 また, Fig. 3 で加熱による $D_{1}$ から $D_{2}$ への減少量に関し ては， $D_{1}$ (・印と $\boldsymbol{\Delta}$ 印）が共晶組成で極大值を示すこ と, 縦軸が対数目盛りであるのでより下側にある $D_{2}$ (○印と $\triangle$ 印) の変化量は $D_{1}$ に比べて非常に小さいこと を合わせ考慮する事によって，加熱による $D_{1}$ から $D_{2}$ への減少量は共晶が多いほど大きいと判断した。そし て，この事実は加熱効果が共晶組織の形態変化に基づく ことを支持している。なお，過共晶組成に入って見られ る $D_{1}$ の低下は, 後で述べるように初晶シリコンの複雑 な形態にあると思われる。

$\mathrm{ND}$ 鋳塊の組織的な特徵と共晶シリコンの形態や分布 に関するデータをまとめて Fig. 4 に示す。マイクロビ ッカース硬度（Fig. 4(1)）はシリコン添加とともに増 大する。加熱によっても軟化しない。初晶 $\alpha-\mathrm{Al}$ の DAS（デンドライト 2 次枝間距離）（Fig. 4(2)）はシリ コン添加によって急減する。亜共晶の初晶 $\alpha-\mathrm{Al}$ と過共 晶のスケルトン状初晶シリコンの外形寸法はいずれも加 熱による変化はない。また, 同図中に, 共晶シリコンの 長さ (3), 厚さ (4), 粒子間距離(5)をそれぞれ平均值で 示したが，凝固方向あるいは熱流方向に指向成長した薄 


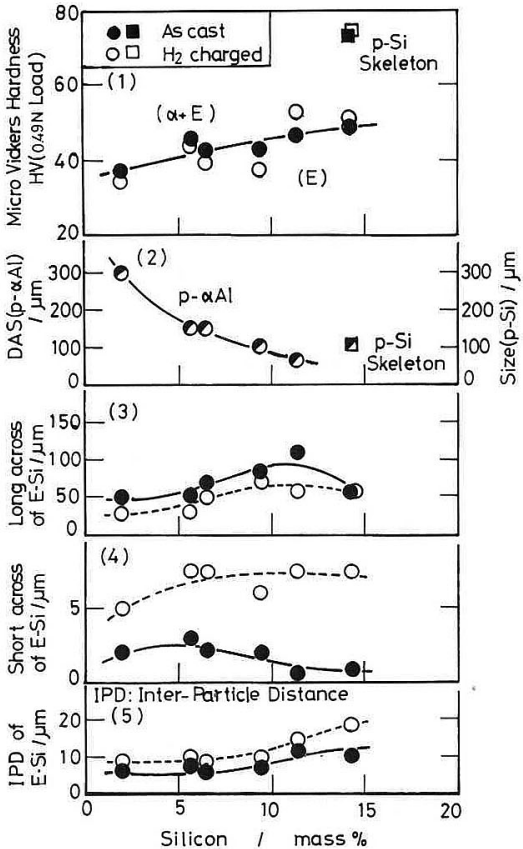
micro Vickers hardness, (2) DAS, dendrite secondary arm spacing, (3) averaged long across and (4) short across of eutectic silicon particles, (5) IPD, inter-particle distance of eutectic silicon. The heating effect is connected with the granulation of thin platelike silicon particles.
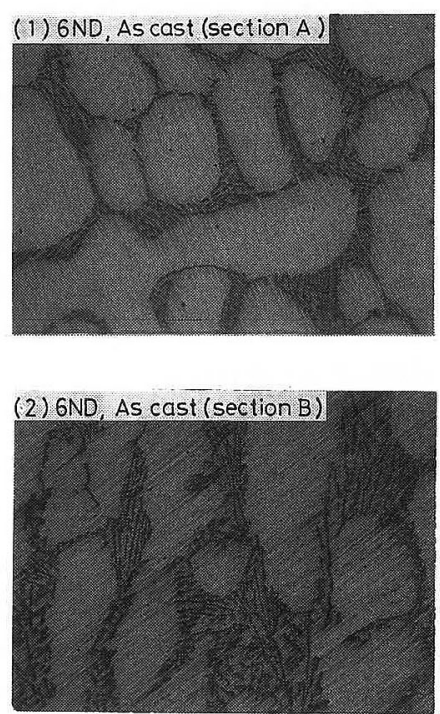

Fig. 4 Silicon concentration dependence of (1) HV,

板状共晶シリコンはその後の加熱によって分断, 凝集, 粒状化，粗大化の傾向を示すことがわかる。

Fig. 5〜Fig. 7 は代表的な亜共晶（6ND），共晶 (11ND)，過共晶（14ND）鋳塊の組織（As cast の状態） と加熱による変化 ( $\mathrm{H}_{2}$ charged と表示) をそれぞれ示 したものである。ND 鋳塊組織と加熱効果の特徵として は，(1) Fig. 6 の(1)と（3）あるいは(2)と（4）を比較して わかるよらに, 板状の共晶シリコンが分断, 凝集し, 一 部粒状化する，(2) Fig. 5 からわかるよ5に, 凝固方向 に長く伸びた $\alpha-\mathrm{Al}$ の樹枝状外形が変わらず, 共晶領域 と区別できる，(3) Fig.7からわかるよらに，初晶シリ コンは多角形塊状ではなく指向成長した微細ラメラーか らなるスケルトン形状である，といったような点があげ られる。

亜共晶の場合, 初晶 $\alpha-\mathrm{Al}$ デンドライトとその間隙に ある板状共晶シリコンは同じ方向に指向整列している。 著者ら ${ }^{3)}$ は純アルミニウムの結晶粒度を変えて水素拡散 係数を実測し, 清浄で直線的 (平滑) な結晶粒界面は水 素の高速拡散経路となりらることを報告した。本研究で は板状共晶シリコン表面をマトリクスとの指向性平滑境 界面とみなし，これに沿ら高速拡散効果を予想した。こ れが比較的低温部での拡散係数増大傾向の原因であろ ら。もし, シリコン結晶中の水素拡散係数がアルミニウ ム中のそれより大きければ，連続的に配列した板状シリ コン粒子が高速拡散経路になる可能性がある。しかし， Buda et $\mathrm{al}^{11)}$ の報告によれば, 次式に示すようにシリコ
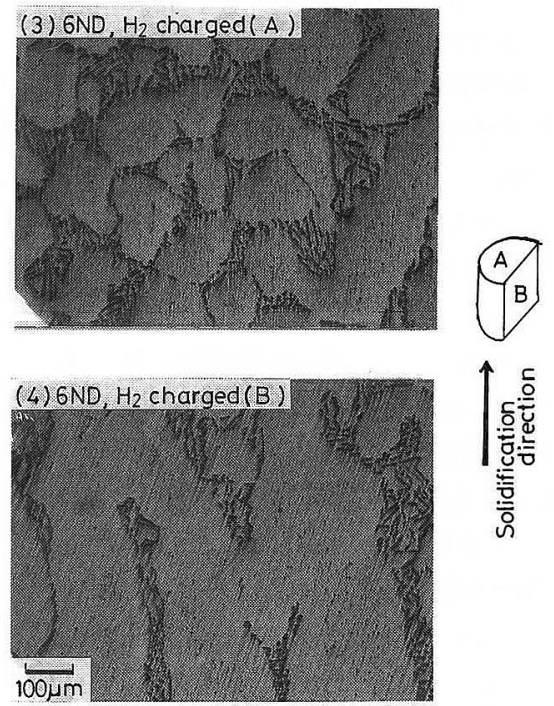

Fig. 5 Typical micro structures in the hypo-eutectic ingot of 6ND for as cast condition (1) and (2), and after all examinations of hydrogen charging and extraction (3) and (4). The plane observed in (1) and (3) is the horizontal section (A) of cylindrical samples, and in (2) and (4) is the vertical section (B) along with the solidification direction. 

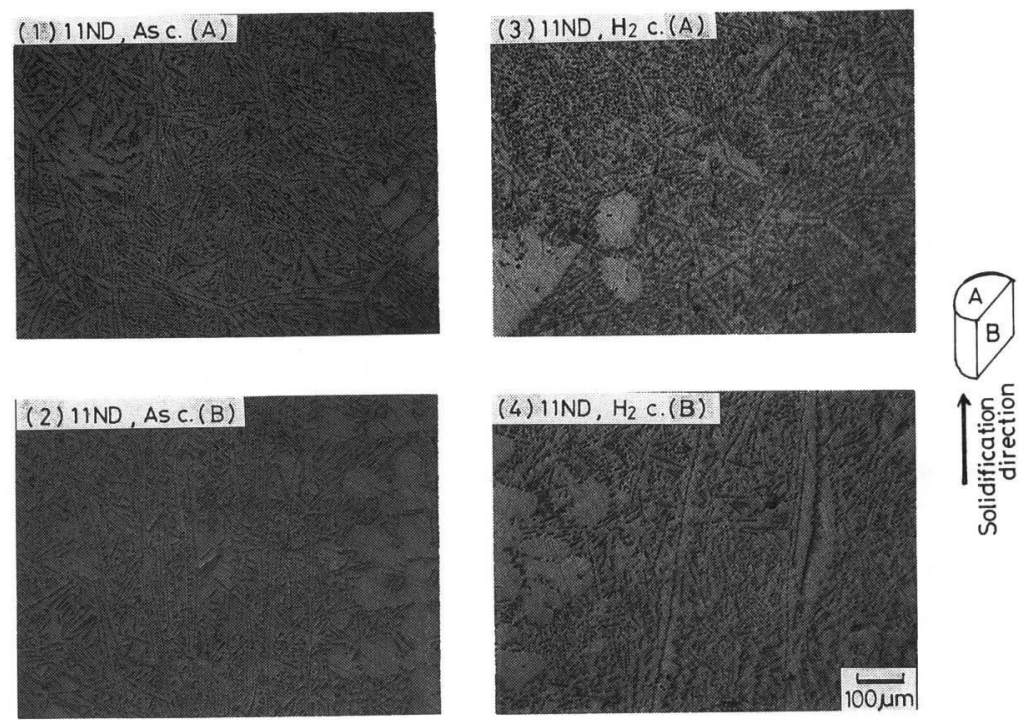

Fig. 6 Typical microstructures in the eutectic ingot of 11 ND and the heating effects.
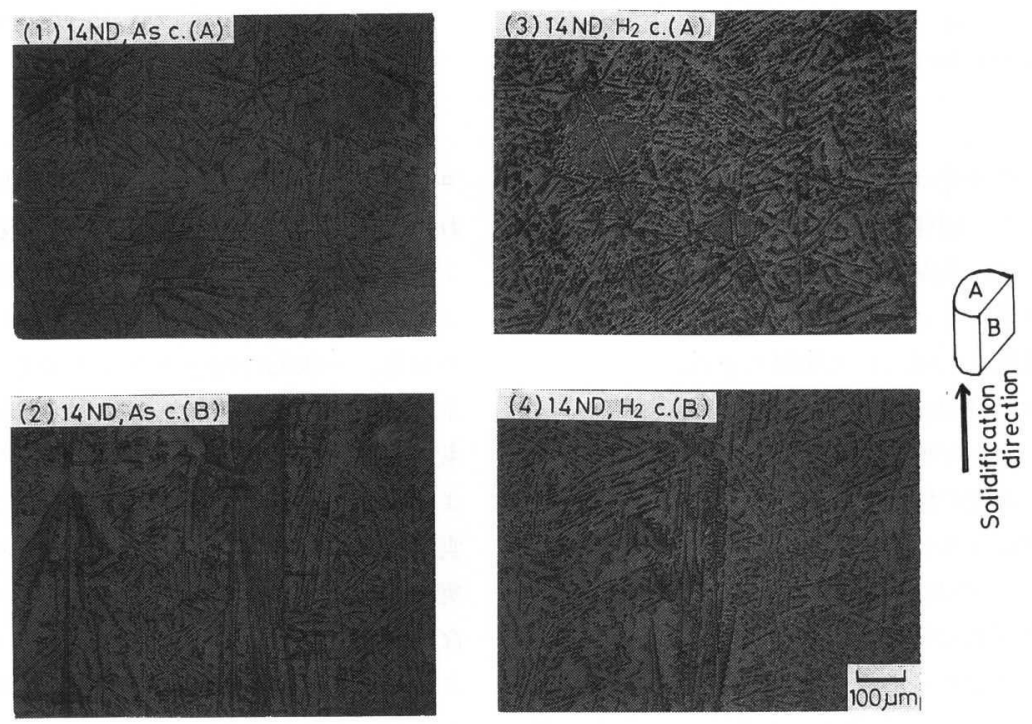

Fig. 7 Typical microstructures in the hyper-eutectic ingot of 14ND and the heating effects.

ン中の水素拡散係数はアルミニウムのそれより 1 桁程度 小さいので, シリコン中水素高速拡散の可能性は少な い。

$$
\begin{aligned}
D= & 9.41 \times 10^{-7}\left(\mathrm{~m}^{2} / \mathrm{s}\right) \exp [-46.3(\mathrm{~kJ} / \mathrm{mol}) / R T], \\
& \text { room temp. } \sim 1300 \mathrm{~K}
\end{aligned}
$$

一方, 加熱の影響としては, 実験中の高温加熱が板状 シリコンを分断凝集粒状化し, シリコン粒子表面（マト リクス境界面）の高速拡散経路を破壊して, 払散係数を 減少させたものとして理解できる。加熱による拡散係数 低下が主として共晶シリコンの形態変化によるとすれ
ば，加熱効果は共晶量に比例することになる（Fig. 3 参 照)。

著者ら ${ }^{12)}$ は最近, 大気溶解, 金型鋳造した $\mathrm{Al}-\mathrm{Si}$ 共晶 合金鋳塊（12AM）の As cast 試料を用いて, $673 \mathrm{~K}$ と $823 \mathrm{~K}$ で繰返し加熱実験を行い, 小板状共晶シリコンの 熱的安定性をチェックした。その結果, as castの共晶 シリコンの形態は $973 \mathrm{~K}-2 \mathrm{~h}$ 加熱ではほとんど変化しな いが, 引続き $823 \mathrm{~K}-1 \mathrm{~h}$ の加熱を行らことで急激に粒状 粗大化し, その後はほとんど変化しないことを認めた。 つまり, 板状共晶シリコンは熱的にかなり不安定であ 


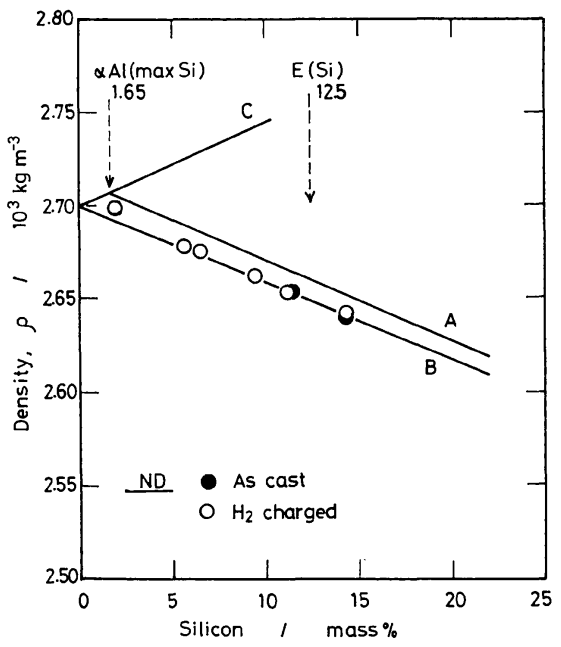

Fig. 8 Silicon concentration dependences of the measured density and three calculated density lines of A, B and C. C is for the $\alpha$-aluminum solid solution with silicon. $\mathrm{A}$ is for the eutectic at $850 \mathrm{~K}$ of $\alpha-$ aluminum ( 1.65 mass $\% \mathrm{Si}$ ) and pure silicon. $\mathrm{B}$ is for in equilibrium at room temperature consisting of pure aluminum and pure silicon.

り，粒状への形態変化は高温短時間の加熱で起こること がわかった。また，同様の加熱条件で行った水素払散㐿 数の測定によれば，高温短時間の加熱により拡散係数が 減少し，板状共晶シリコンの粒状化に対応することも認 めた。本実験結果も同様にして理解できる。

ND 各鋳塊の密度測定結果をFig. 8 亿示す。アルミ ニウム中にシリコンが固溶すると $\alpha-\mathrm{Al}$ 固溶体の格子定 数 ${ }^{13)}$ は減少し, 密度が増加する（直線 $\mathrm{C}$ )。 $\alpha-\mathrm{Al}$ の最大 シリコン固溶限以上では, 初晶 $\alpha-\mathrm{Al}$ 固溶体に加えて, $\alpha-\mathrm{Al}$ と純シリコンの共晶組織が生成する。このとき， シリコンの密度を $2.329\left(10^{3} \cdot \mathrm{kg} \cdot \mathrm{m}^{-3}\right)$ として, シリコン 濃度上昇に伴う合金密度の減少を計算した（直線 A)。 直線 A は共晶温度での平衡凝固注対応する。一方, 低 温では $\alpha-\mathrm{Al}$ 中のシリコン溶解度が急減して純アルミ ウムと純シリコンの共存状態に近くなる（直線 B)。直 線 B は室温平衡に対応する。実測結果は直線 A と B 間にあり B に近い。この結果から，密度低下をもたら す微小空洞などのガス欠陥は一方向凝固によって完全に 除去されていると判断した。なお，加熱による密度变化 は見られなかった。

Fig. 9 は ND 鋳塊 6 試料の623〜823 Kにおける水素 溶解度をアレニウスプロットで示したものである。大き なばらつきはあるが，2ND $\rightarrow 14 \mathrm{ND}$ に向けてシリコン添 加による水素溶解度の増加傾向が認められた。この原因 としては, 共晶シリコン, 初晶シリコンおよび析出シリ

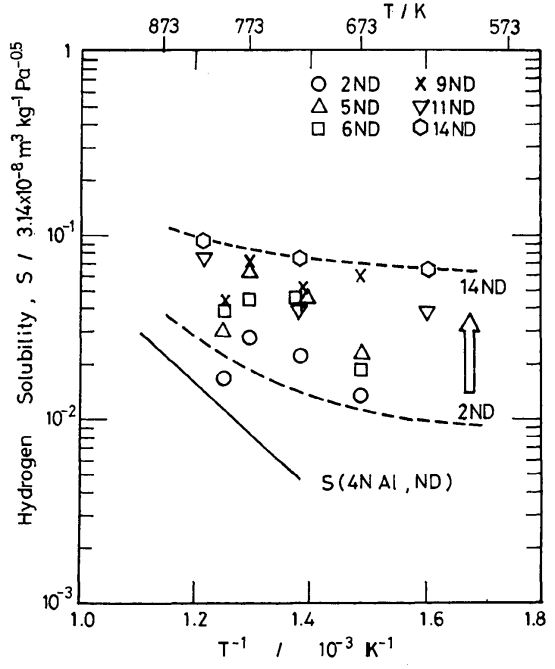

Fig. 9 Relation between the hydrogen solubilities and hydrogen charging temperatures for six $\mathrm{Al}-\mathrm{Si}$ ingots of 2ND $14 \mathrm{ND}$ comparing with the solubility for pure aluminum, $S(4 \mathrm{NAl}, \mathrm{ND})$. Silicon additions have a tendency to increase the hydrogen solubilities in $\mathrm{Al}-\mathrm{Si}$ alloys.

コンなどの各種シリコン粒子と水素の相互作用が考えら れる。本実験では水素チャージの状態で板状共晶シリコ ンの分断粒状化がかなり進んでいるので，孤立型のシリ コン粒子の表面は水素のトラップサイトとして働き，そ の結果, 一般的な粒子トラップ効果3),4) として, 見かけ 上の水素溶解度を増大させる可能性がある。他方，もし もシリコン粒子自身の水素溶解度がアルミニウムのそれ よりも大きければ，シリコン添加によって水素溶解度は 当然増加するが, 現時点ではシリコン中の水素溶解度が 実測されていないので，この点については不明である。 なお，ND 鋳塊はガス欠陥を含まないので，ボイド等に よる分子状水素ガスのトラップに基づく水素溶解度の增 大はないと考旮よい。

本実験の ND 鋳塊の加熱効果は前報10) AM 鋳塊のそ れに比べてょり著しい。この理由は,より長大な ND の板状共晶シリコンが分断粒状化するためであるといえ よ5。アルミニウム合金鋳塊に打ける水素の挙動は複雑 であり, 鋳塊組織全般の影響を強く受ける。特に, 水素 払散係数や水素溶解度の評価にあたっては, ガス欠陷を はじめとして結晶粒度, 初晶・共晶の構成相の形態, サ イズ，分布とそれらの熱的安定性など，いわゆる鋳塊組 織全般について十分の留意が必要である。

\section{4. 結言}

2〜14 mass\% $\mathrm{Si}$ を含を 6 種類の $\mathrm{Al}-\mathrm{Si} 2$ 元合金を窒素 
雾囲気中で溶解後，一方向凝固させたND鋳塊を用い

て，水素払散係数と溶解度を真空加熱ガス抽出法によっ て測定した。実測値の温度依存性とシリコン濃度依存性 を比較検討して以下の結論を得た。

(1) As cast 試料の水素拡散係数 $\left(D_{1}\right)$ は加熱によっ て水素チャージ後の值 $\left(D_{2}\right)$ 入減少する。

(2) $D_{1}$ と $D_{2}$ はともにアレニウスプロットで直線とな らず，下に凸の曲線となる。約 $672 \mathrm{~K}$ 付近の $D_{2}$ の低下 は, 高温水素チャージ後の急冷によって過飽和となった $\alpha-\mathrm{Al}$ 中の析出シリコン微細粒子による水素トラップ効 果に基づくものと思われる。

(3) $673 \mathrm{~K}$ なは773 K における $D_{1}$ と $D_{2}$ はいずれも シリコン添加によりまず減少し，極小值を経て増大す る。 $D_{1}$ と $D_{2}$ の差は共晶シリコン量に対応する。

（4） $D_{1}$ から $D_{2}$ への水素払散係数低下をもたらす加熱 効果の主原因は共晶シリコンの形態変化にあり, 水素扗 散のモードは界面高速型から粒子トラップ型に変化する ようである。

（5） 水素溶解度はシリコン添加によって増大する。

\section{参考文 献}

1）市村 稔, 今林 守, 早川政広：日本金属学会誌, 43 (1979), 876.

2) M. Ichimura, H. Katsuta, Y. Sasajima and M. Imabayashi: J. Phys. Chem. Solids, 49 (1988), 1259.

3) M. Ichimura, Y. Sasajima and M. Imabayashi: Mater. Trans. JIM, 32 (1991), 1109.

4) M. Ichimura, Y. Sasajima and M. Imabayashi: Mater. Trans. JIM, 33 (1992), 449.

5) R. Eborall and C. E. Ransley: J. Inst. Metals, 71 (1945), 525.

6）西 成基, 黒淵達史：軽金属，24（1974），17.

7) P. N. Anyalebechi: Metall. Trans., 21B (1990), 649.

8）市村稔，篠嶋妥，今林守：軽金属，39 (1989), 639 .

9）市村稔, 篠嶋妥, 今林守：軽金属, 40 (1990), 95.

10）市村稔，篠嶋妥，今林守：軽金属，42 (1992), 333 .

11) F. Buda, G. L. chiarotti, R. Car and M. Parrinello: Phys. Rev. Letters, 63 (1989), 294.

12）市村 稔, 篠嶋 妥, 今林 守: 軽金属学会第 83 回秋期大会講演概要 No. 46, (1992), 91.

13）金属データブック, 日本金属学会編, 丸善(1974), 52. 